\title{
PROSPEK HUKUM ISLAM DI BIDANG PENGUATAN MONETER DENGAN PEMBERLAKUAN MATA UANG DINAR DAN DIRHAM*
}

\author{
Rahmat Fauzi \\ STIH Putri Maharaja Payakumbuh, \\ Guguak Randah Kenagarian Guguak Tabek Sarojo Kec. IV Koto Kab. Agam \\ e-mail: rahmatfauzi24oke@gmail.com
}

\begin{abstract}
The limitation of the use of coins lies in its weight, so that since before Islam, in addition to the currency of the dinar and dirham, also apply to the trade papers and bonds (credit) for large commercial transactions. In running his government, at least the Prophet set nine policies in the field of monetary, among them are: First, let the currency of dinar and dirhams and trade notes and bonds payable. Second, the exemption of tariffs and import duties on imports of gold and silver and commodities from the Persian and Roman regions. Third, the prohibition of money accumulation (kanz). Fourth, the prohibition of stockpiling to maintain the stability of the value of money. Fifth, the prohibition of lending money (riba) which is run along with the prohibition of hoarding money (kanz) has accelerated the circulation of money directed to investment activities. Sixth, encourage interest-free loans (qardhul hasan) and profit sharing and risk sharing models. Seventh, prevent speculative activities. Eighth, increasing the production of goods and services. Ninth, the abolition of the trade monopoly of the Quraysh in Ukaz and Dul-Majaz markets after the conquest of Mecca. The removal of this monopoly improves the efficiency and distribution of better income. Effective demand and demand for money transactions increased so as to speed up the circulation of money.
\end{abstract}

Keywords: Islamic Law, Strengthening, Currency, Dinar and Dirham

\begin{abstract}
Abstrak
Keterbatasan penggunaan mata uang logam terletak pada beratnya, sehingga sejak sebelum Islam, selain berlaku mata uang dinar dan dirham, berlaku pula surat wesel dagang dan surat utang (kredit) untuk transaksi dagang yang besar. Dalam menjalankan pemerintahannya, setidaknya Rasulullah menetapkan sembilan kebijakan di bidang moneter, diantaranya adalah: Pertama, membiarkan berlakunya mata uang dinar dan dirham serta surat wesel dagang dan surat utang. Kedua, pembebasan tarif dan bea masuk untuk impor emas dan perak serta komoditi dari wilayah Persia dan Romawi. Ketiga, larangan penimbunan uang (kanz). Keempat, larangan penimbunan barang untuk menjaga stabilitas nilai uang. Kelima, larangan membungakan uang (riba) yang dijalankan bersama dengan larangan menimbun uang (kanz) telah mempercepat peredaran uang yang diarahkan untuk kegiatan investasi. Keenam, menggalakkan pinjaman tanpa bunga (qardhul hasan) dan model-model perjanjian bagi hasil dan resiko. Ketujuh, mencegah kegiatan spekulasi. Kedelapan, meningkatkan produksi barang dan jasa. Kesembilan, penghapusan monopoli dagang kaum Quraisy di pasar Ukaz dan Dul-Majaz setelah penaklukan Mekkah. Penghapusan monopoli ini meningkatkan efisiensi dan distribusi pendapatan yang lebih baik. Permintaan efektif dan permintaan transaksi terhadap uang meningkat sehingga mempercepat peredaran uang.
\end{abstract}

Kata kunci: Hukum Islam, Penguatan, Mata Uang, Dinar Dan Dirham

\footnotetext{
* Naskah diterima: 02 Maret 2018, direvisi: 25 Maret 2018, disetujui untuk terbit: 27 Maret 2018
} 
Rahmat Fauzi: Prospek Hukum Islam Di Bidang Penguatan Moneter Dengan Pemberlaku..

\section{PENDAHULUAN}

Periode awal Islam yang terdiri dari era kenabian Muhammad SAW dan era Khulafaur Rasyidin merupakan rentang waktu yang sangat penting dalam sejarah Islam. Sebabnya adalah, pada periode ini ajaran Islam yang komprehensif yang meliputi seluruh aspek kehidupan, baik ibadah, sosial, politik, maupun ekonomi betul-betul diimplementasikan. Dengan kata lain, periode awal Islam merupakan prototipe ideal yang harus ditiru oleh masyarakat kita sekarang. ${ }^{1}$

Islam sungguh telah membawa transformasi radikal dalam kehidupan individual dan sosial bagi penganutnya. Ia telah merombak secara total perilaku keseharian, sebagaimana juga merombak standar-standar, penilaian, dan cara pandang seseorang terhadap kehidupan. Inilah yang terjadi pada generasi periode awal Islam. Pengaruh iman dan akidah Islam sangat kuat membentuk karakter masyarakat kaum muslimin. Karena itu, struktur masyarakat yang terbentuk pada periode ini adalah suatu masyarakat yang motif-motif perilakunya sangat dipengaruhi oleh motivasi untuk memperoleh keridhaan Allah dan pahala akhirat.

Dampak dahsyat dari pengaruh motivasi tersebut pada generasi periode awal itu merefleksi secara jelas bahwa keikutsertaan mereka dalam pertempuran militer yang dikenal dengan al-futuhat

1 Karnaen A. Perwataatmadja, 2008, Jejak Rekam Ekonomi Islam Refleksi Peristiwa Ekonomi dan pemikiran Para Ahli Sepanjang Sejarah Kekhalifahan, Cicer Publishing, Jakarta, Hlm. 17 (pembukaan suatu wilayah/ekspansi) sama sekali tidak termotivasi oleh ambisi duniawi.

Dilatarbelakangi ramainya jalur perdagangan antara Persia dan Romawi serta daerah jajahannya seperti: Syam, Ethiopia dan Yaman di utara, dan dari Romawi jalur perdagangan antara Roma dan India di selatan, pasar-pasar musiman tumbuh di Yaman, Hijaz, San'a, Yatsrib, dan Mekah. Pada mulanya transaksi dilakukan secara barter namun pada perkembangan selanjutnya diperlukan alat tukar yang berlaku umum yaitu emas dan perak untuk mempermudah transaksi. ${ }^{2}$

Jika kita lihat perkembangan yang terjadi hari ini, penggunaan mata uang kertas sudah menjadi keseharian kita. Sedangkan ini merupakan uang kosong yang sebenarnya tidak ada nilainya. Maka, bagaimanakah prospeksi dinar dan dirham dalam peranannya menyejahterakan masyarakat dunia?

\section{METODE PENELITIAN}

Penelitian yang dilaksanakan adalah penelitian hukum normatif, ${ }^{3}$ yaitu penelitian terhadap taraf sinkronisasi

\footnotetext{
${ }^{2}$ Ibid, Hlm. 38

${ }^{3}$ Penelitian ini disebut juga penelitian hukum doktrinal atau penelitian yuridis normatif atau penelitian terhadap law in book, lihat Sutomo, Skripsi UNAND Tahun 2002, lebih lanjut lihat Bambang Sunggono, 2001, Metodologi Penelitian Hukum, Jakarta, Hlm. 97, dan berdasarkan catatan kuliah Metode Penelitian Ilmu Hukum pada Magister Kenotariatan UGM Kerjasama UNAND tahun 2009 yang diberikan oleh Prof. Dr. Sudjito, SH., M.Si, penelitian ini dinamakan juga jenis atau bentuk penelitian studi kasus karena penelitian ini bersifat unik, pantas diteliti, dan yang dicari kebenaran khusus, mendalam, utuh.
} 
hukum secara horizontal. ${ }^{4}$ Jenis data dalam penelitian ini yaitu data sekunder, dengan metode pengumpulan data secara bibliografi, yaitu data yang diperoleh dari studi kepustakaan. Analisis data yang dipakai adalah analisis data secara kualitatif yaitu bertujuan memahami, menginterpretasikan, mendeskripsikan suatu realitas.

\section{HASIL DAN PEMBAHASAN}

\section{A. Perkembangan Kebijakan Bidang Penguatan Moneter Dengan Pemberlakuan Mata Uang Dinar Dan Dirham di Pemerintahan Islam}

\section{Kebijakan Moneter pada Masa Pemerintahan \\ Nabi Muhammad SAW}

Bangsa arab di Hijaz pada masa jahiliah belum memiliki mata uang tersendiri. Mereka menggunakan mata uang yang mereka peroleh berupa Dinar Emas Hercules, Byziantum dan Dirham perak Dinasti Sasanid dari Iraq, dan sebagian mata uang bangsa Himyar, Yaman.

Kabilah Quraish mempunyai tradisi melakukan perjalanan dagang dua kali dalam setahun; ketika musim panas ke negeri Syam (Syria,sekarang) dan pada musim dingin ke negeri Yaman. Firman Allah SWT:

Karena kebiasaan orang-orang Quraisy, (yaitu) kebiasaan mereka bepergian pada musim dingin dan

4 Merupakan bentuk penelitian hukum normatif untuk mengetahui sejauhmana hukum positif tertulis yang ada sinkron atau sesuai satu sama lainnya. musim panas. Maka hendaklah mereka menyembah Tuhan pemilik rumah ini (Ka'bah). Yang telah memberi makan kepada mereka untuk menghilangkan lapar dan mengamankan mereka dari ketakutan (QS Al-Quraisy [106]:1-4).

Penduduk Mekkah tidak memperjualbelikan kecuali sebagian emas yang tidak ditempa dan tidak menerimanya kecuali dalam ukuran timbangan. Mereka tidak menerima dalam jumlah bilangan. Hal ini disebabkan beragamnya bentuk dirham dan ukurannya dan munculnya penipuan pada mata uang mereka seperti nilai tertera yang melebihi dari nilai yang sebenarnya. $^{5}$

Ketika Nabi SAW diutus sebagai nabi dan rasul oleh Allah SWT, beliau menetapkan apa yang sudah menjadi tradisi penduduk Mekkah. Dan beliau memerintahkan penduduk Madinah untuk mengikuti ukuran timbangan penduduk Mekkah ketika itu mereka berinteraksi ekonomi dengan menggunakan Dirham dalam jumlah bilangan bukan ukuran timbangan. Beliau bersabda: "Timbangan adalah timbangan penduduk Mekkah sedang takaran adalah takaran penduduk madinah".

Sebab munculnya perintah itu adalah perbedaan ukuran dirham Persia karena terdapat tiga bentuk cetakan uang:

1. Ukuran 20 qirath (karat);

2. Ukuran 12 karat;

\footnotetext{
${ }^{5}$ Hasan Ahmad, 2005, Mata Uang Islam, PT. Raja Grafindo Persada, Jakarta, Hlm. 32. Dikutip dalam Rezallih, Sejarah dan Konsep uang dalam Islam, dikutip dalam http://hendrakholid.net/blog/2009/12/21/357/, pada tanggal 18 Oktober 2010 jam 8.23 WIB.
} 
Rahmat Fauzi: Prospek Hukum Islam Di Bidang Penguatan Moneter Dengan Pemberlaku..

3. Ukuran 10 karat

Dilatarbelakangi ramainya jalur perdagangan antara Persia dan Romawi serta daerah jajahannya seperti: Syam, Ethiopia dan Yaman di utara, dan dari Romawi jalur perdagangan antara Roma dan India di selatan, pasar-pasar musiman tumbuh di Yaman, Hijaz, San'a, Yatsrib, dan Mekah. Pada mulanya transaksi dilakukan secara barter namun pada perkembangan selanjutnya diperlukan alat tukar yang berlaku umum yaitu emas dan perak untuk mempermudah transaksi. ${ }^{6}$

Menurut Dr. Kadim as-Sadr, Arabia dan wilayah-wilayah tetangganya berada di bawah kekuasaan Romawi dan Persia, sehingga di wilayah itu berlaku mata uang emas dari Romawi disebut Dinar dan mata uang perak dari Persia disebut Dirham. Koin dinar dan dirham mempunyai berat yang tetap dimana nilai satu dinar sama dengan sepuluh dirham. Bilai emas dan perak pada kepingan dinar dan dirham sama dengan nilai nominalnya (face value). Dengan masuknya seluruh Jazirah Arab pada zaman pemerintahan Nabi Muhammad SAW, maka di wilayah itu berlaku mata uang dinar dan dirham, namun dirham lebih populer di dunia usaha bangsa Arab.

Keterbatasan penggunaan mata uang logam terletak pada beratnya, sehingga sejak sebelum Islam, selain berlaku mata uang dinar dan dirham, berlaku pula surat wesel dagang dan surat utang (kredit) untuk transaksi dagang yang besar. 38.

\footnotetext{
${ }^{6}$ Karnaen A. Perwataatmadja, Op.Cit, Hlm.
}

Dalam menjalankan pemerintahannya, setidaknya Rasulullah menetapkan sembilan kebijakan di bidang moneter, diantaranya adalah: ${ }^{7}$

Pertama, membiarkan berlakunya mata uang dinar dan dirham serta surat wesel dagang dan surat utang. Dengan berlakunya mata uang dinar dan dirham, maka secara otomatis terjadi permintaan dan penawaran terhadap kedua mata uang itu. Apabila permintaan dinar meningkat, dinar diimpor dari wilayah kekuasaan Romawi dengan cara mengekspor komoditi yang laku di wilayah itu. Demikian pula halnya dirham yang diimpor dari wilayah kekuasaan Persia dengan tukaran komoditi yang laku dijual di sana. Sebaliknya, apabila terjadi peningkatan penawaran dinar atau dirham, maka komoditilah yang diimpor dari kedua wilayah itu.

Kedua, pembebasan tarif dan bea masuk untuk impor emas dan perak serta komoditi dari wilayah Persia dan Romawi. Dengan bertubi-tubinya serangan kaum kafir Quraisy (tercatat 58 kali peperangan atau rata-rata enam kali dalam setahun), kegiatan perdagangan melalui wesel dagang atau surat utang menjadi terbatas dan ekspor-impor menjadi terganggu. Akibatnya, terjadi tindakan penyimpangan mata uang dinar dan dirham. Motivasi penyimpangan ternyata semata-mata hanya untuk keperluan transaksi (transaction motive) dan untuk keperluan jaga-jaga (precausinary motive) karena Rasulullah telah melarang penimbunan uang (kanz).

\footnotetext{
${ }^{7}$ Ibid, Hlm. 39
} 
Ketiga, larangan penimbunan uang (kanz). Sementara itu, masyarakat dibolehkan meleburkan uang emas dengan perak menjadi perhiasan atau ornamen ketika ada kelebihan penawaran di atas permintaannya.

Keempat, larangan penimbunan barang untuk menjaga stabilitas nilai uang. Distorsi harga dicegah melalui larangan pencegahan kafilah sebelum masuk ke pasar (talaqqir rukban).

Kelima, larangan membungakan uang (riba) yang dijalankan bersama dengan larangan menimbun uang (kanz) telah mempercepat peredaran uang yang diarahkan untuk kegiatan investasi.

Keenam, menggalakkan pinjaman tanpa bunga (qardhul hasan) dan modelmodel perjanjian bagi hasil dan resiko. Kebijakan ini berlaku untuk kaum Anshar dan kaum Muhajirin dalam bentuk Mudharabah (pihak yang satu menyediakan modal dan pihak yang lain menyediakan keahlian berusahanya), muzara'ah (pembagian panen), musaqat (pihak yang satu menyediakan kebun dan pihak yang lain mengatur irigasi serta tenaga kerja), dan musyarakah (masingmasing pihak menyediakan modal). Adanya kebijakan ini telah meningkatkan produksi yang pada gilirannya ikut mempercepat peredaran uang.

Ketujuh, mencegah kegiatan spekulasi. Nabi Muhammad SAW melarang uang dan barang dipertukarkan (jual beli) selang beberapa waktu setelah kontrak ditandatangani atau sekarang disebut future trading.
Kedelapan, meningkatkan produksi barang dan jasa. Hal ini dilakukan dalam bentuk pembagian tanah yang ditinggalkan Bani Nadhir dan pembagian tanah untuk perumahan, melakukan alih pengetahuan dan keterampilan dari Persia dan Romawi untuk kegiatan pertanian, arsitektur, kedokteran, dan kerajinan sehingga hasil pertanian, kerajinan, dan kegiatan di bidang jasa meningkat.

Kesembilan, penghapusan monopoli dagang kaum Quraisy di pasar Ukaz dan Dul-Majaz setelah penaklukan Mekkah. Penghapusan monopoli ini meningkatkan efisiensi dan distribusi pendapatan yang lebih baik. Permintaan efektif dan permintaan transaksi terhadap uang meningkat sehingga mempercepat peredaran uang.

Kesembilan kebijaksanaan tersebut di atas, dilaksanakan dengan baik sehingga selama pemerintahan Nabi Muhammad SAW tidak terdapat catatan adanya gejolak moneter.

\section{Kebijakan Moneter pada Masa Pemerintahan Khulafaur Rasyidin}

Ketika Abu Bakar di baiat menjadi khalifah, beliau tidak melakukan perubahan terhadap mata uang yang beredar. Bahkan menetapkan apa yang sudah berjalan pada masa Rasulullah, yaitu penggunaan mata uang Dinar Haercules dan Dirham Persia.

Begitu pula ketika Umar bin Khattab di baiat sebagai khalifah, sibuk melakukan penyebaran Islam ke berbagai negara dan menetapkan uang sebagai 
Rahmat Fauzi: Prospek Hukum Islam Di Bidang Penguatan Moneter Dengan Pemberlaku..

mana yang sudah berlaku. Hanya pada tahun $18 \mathrm{H}$, menurut riwayat tahun $20 \mathrm{H}$, dicetak Dirham Islam. Akan tetapi Dirham tersebut, bukan cetakan asli Islam, akan tetapi masih mengikuti model cetakan Sasanid berukiran Kisra dengan beberapa tambahan berupa ukiran di lingkaran yang meliputi ukiran Kisra ditambah ukiran beberapa kalimat tauhid dalam jenis tulisan Kufi, seperti kalimat Bismillah, Bismillah Rabbi, Alhamdulillah, dan pada sebagian lagi kalimat Muhammad Rasulullah.

Ukuran Dirham Islam ketika itu adalah 6 daniq dan ukuran setiap 10 dirham adalah 7 mitsqal sebagaimana pada masa Nabi Saw. Ketika itu ukuran hanya dalam ingatan maka pada masa Umar dituliskan di cetakan dirham.

Pada masa Ustman bin Affan, dicetak dirham seperti model dirham Khalifah Umar bin Khattab dan ditulis juga kota tempat pencetakan dan tanggalnya dengan huruf Bahlawiyah dan salah satu kalimat Bismillah, Barakah, Bismilah Rabbi, Allah, dan Muhammad dengan jenis tulisan Kufi.

Ketika Ali bin Abi Talib menjadi khalifah, beliau mencetak dirham mengikuti model kahlifah Usman bin Affan dan menuliskan di lingkarannya salah satu kalimat Bismillah, Bismillah Rabbi, dan Rabiyallah dengan jenis tulisan Kufi.

\section{Kebijakan Moneter pada Masa Pemerintahan Dinasti Umayyah}

Pencetakan uang pada masa dinasti Umawiyah semenjak masa Muawiyah bin Abi Sofyan masih meneruskan model Sasanid dengan menambahkan beberapa kata tauhid seperti halnya pada masa Khulafaurrasyidin.

Pada masa Abdul Malik bin Marwan, setelah mengalahkan Abdullah bin Zubair dan Mush'ab bin Zubair, beliau menyatukan tempat percetakan. Dan pada tahun $76 \mathrm{H}$, beliau membuat mata uang Islam yang bernafaskan model Islam tersendiri, tidak ada lagi isyarat atau tanda Byzantium atau Persia. Dengan demikian, Abdul Malik bin Marwan adalah orang yang pertama kali mencetak dinar dan dirham dalam model Islam tersendiri.

\section{Kebijakan Moneter pada Masa Pemerintahan Dinasti \\ Abassiyah}

Pada masa Abbasiah, pencetakan dinar masih melanjutkan cara Dinasti Umawiyah. Al-Saffah mencetak dinarnya yang pertama pada awal berdirinya Dinasti Abbasiah pada tahun $132 \mathrm{H}$ mengikuti model dinar Umawiyah dan tidak mengubah sedikitpun kecuali pada ukiran-ukirannya. ${ }^{8}$

Sedangkan dirham, pada awalnya ia kurangi satu butir kemudian dua butir. Pengurangan ukuran dirham terus berlanjut pada masa Abu Ja'far alManshur, dia mengurangi tiga butir hingga pada masa Musa al-Hadi

\footnotetext{
${ }^{8}$ Hasan Ahmad, Loc.Cit.
} 
kurangnya mencapai satu karat. Dinar menjadi tidak seperti aslinya, pengurangan terus terjadi setelah itu. Namun demikian nilainya, nilainya tetap dihitung seperti semula. Al-Maqrizy berkata: "Pada bulan Rajab tahun 191, dinar Hasyimiah mengalami pengurangan sebanyak setengah butir dan hal itu terus berlanjut sepanjang periode tapi masih berlaku seperti semula".

Dengan demikian kita dapat membedakan dua fase pada masa Dinasti Abbasiah. Fase pertama, terjadi pengurangan terhadap ukuran dirham kemudian dinar. Fase kedua, ketika pemerintahan melemah dan para pembantu (Mawali) dari orang Turki ikut seta dalam urusan Negara. Ketika itu pembiayaan semakin besar, orang-orang sudah menuju kemewahan sehingga uang tidak lagi mencukupi kebutuhan. Negara pun membutuhkan bahan baku tambahan, terjadilah kecurangan dalam pembuatan dirham dan mencampurkannya dengan tembaga untuk memperoleh keuntungan dari margin nilai tertulis dengan nilai actual.

Para fuqaha menolak pencetakan dirham yang curang karena terjadi pengrusakan terhadap uang, merugikan yang berhak, dan menyebabkan naiknya harga-harga (inflasi). Inflasi tersebut disebabkan nilai uang dirham tertulis melebihi dari nilai yang sebenarnya.

Ibnu Taimiyyah sebagai salah satu pemikir ekonomi dalam kepemimpinan Abbasiyah II menyatakan dengan gamblang konsep uang. Ia menyebutkan dua fungsi uang yaitu sebagai alat pengukur nilai dan media pertukaran dalam tulisannya tentang karakteristik dan fungsi uang, beliau menyatakan, "Atsman (harta atau yang dibayarkan sebagai harga, yaitu uang) dimaksudkan sebagai pengukur nilai barang-barang yang dengannya jumlah nilai barang-barang dapat diketahui dan uang tidak pernah dimaksudkan untuk mereka sendiri". 9

Berdasarkan pandangan tersebut, Ibnu Taimiyah menentang keras segala bentuk perdagangan uang dari tujuan yang sebenarnya. Apabila uang dipertukarkan dengan uang yang lain, pertukaran tersebut harus dilakukan secara spot (taqabud) dan tanpa penundaan (hulul). Dengan cara ini, seseorang dapat mempergunakan uang sebagai sarana untuk memperoleh berbagai kebutuhannya.

Prinsip-prinsip penting lain yang dikemukakan oleh Ibnu Taimiyyah berkaitan dengan konsep uang dan moneter adalah sebagai berikut:

1. Perdagangan uang akan memicu inflasi

2. Hilangnya kepercayaan orang akan stabilitas nilai uang akan mencegah orang melakukan kontrak jangka panjang dan menzalimi golongan masyarakat berpendapatan tetap seperti pegawai negeri.

3. Perdagangan domestik akan menurun karena kekhawatiran stabilitas nilai uang.

4. Perdagangan internasional akan menurun

\footnotetext{
${ }^{9}$ Karnaen, Op.Cit, Hlm. 161
} 
Rahmat Fauzi: Prospek Hukum Islam Di Bidang Penguatan Moneter Dengan Pemberlaku..

5. Logam berharga akan mengalir keluar negara.

Gresham Law yang menyatakan: "Bad money will drive out good money" yang dikemukakan oleh Thomas Gresham (1857) tampaknya menjiplak rumusan Ibnu taymiyah bahwa uang yang sama nominalnya, tetapi lebih rendah kandungan emasnya, akan mendorong keluar dan menggantikan uang yang kandungan emasnya lebih tinggi. Uang yang lebih tinggi kandungan emasnya itu akan cenderung dilebur dan dijual untuk mendapatkan uang yang kandungan emasnya lebih rendah, karena nilai nominalnya sama. ${ }^{10}$

\section{Kebijakan Moneter pada Masa Khilafah Utsmaaniyyah}

Pada masa Daulah Utsmaniyah, ditemukan proto bank pertama (Galata Sarraf) yang melayani pertukaran mata uang asing, memberikan pinjaman lunak, serta menyediakan pembelian piutang. Akan tetapi, tidak ditemukan adanya indikasi penerimaan tabungan masyarakat padanya.

Dari sudut pandang pengambilan kebijakan ekonomi, para sultan Utsmani dapat dinilai sebagai penguasa yang bekerja secara realistis, jika tidak mungkin disebut pragmatis sesuai dengan ketersediaan dana.

Khilafah islamiayah merupakan simbol kesatuan dan persatuan masyarakat muslimin. Dengan adanya khilafah, kaum muslimin merasa sebagai umat yang kuat, tersohor, disegani kawan

\footnotetext{
${ }^{10}$ Ibid. Hlm. 162
}

maupun lawan. Sepanjang sejarahnya, khilah islamiyah memiliki kharisma, wibawa dan kemuliaan Islam dan umatnya. Sedangkan khlifah adalah pemimpin kaum muslimin di seluruh dunia.

Supremasi khilafah islmiyah telah membuat negara-negara di berbagai penjuru dunia seperti Perancis, Swiss, Rusia, Hungaria, Inggris, Belgia, dan lainnya segan dan takut, sehingga mereka banyak mengirimkan hadiah-hadiah sebagai bukti penghormatan mereka kepada khalifah.

Karena fakta inilah, Inggris mengajukan rancangan yang antara lain berisi, Di antara tugas besar Inggris adalah berpikir dengan serius menumbangkan imperium Utsmaniyah yang membahayakan kepentingan Inggris. Apabila Imperium Utsmani ini merupakan simbol persatuan agama Islam yang kokoh yang dipimpin oleh sultan sebagai khalifah dan pemimpin kaum Muslimin seluruh dunia.

Para Paus sendiri menyadari bahwa salah satu dari mereka, betapa pun kuatnya mungkin mampu mengalahkan khilafah islamiyah, yang direpresentasikan oleh Sultan Turki Utsmani dalam kapasitasnya sebagai Khalifah kaum muslimin di seluruh penjuru dunia.

Para Paus sendiri yang terlibat konflik internal juga mengakui hari ini. Paus V berkata, "Sesungguhnya Imperium Turki berkembang dengan pesat karena ada perpecahan di antara 
kita. Kita akan berhasil mengalahkan Turki jika seluruh raja Eropa bersatu dalam memerangi musuh besar kita ini dan melancarkan serangan kepadanya dari darat, laut, dan udara. Kita yakin sepenuhnya bahwa dalam tubuh umat Kristiani ini tidak ada yang mampu mengalahkan kepada Sultan Turki secara sendirian. Oleh karena itu, alangkah baiknya jika mereka kita panggil untuk bersatu dalam memerangi dan melumpuhkan kesultanan Turki”.

Menindaklanjuti upaya itu, negaranegara Eropa kemudian menyusun seratus strategi untuk menghancurkan kekhalifahan Turki Utsmani. Ikut terlibat dalam penyusunan itu, para pemikir, filosof, panglima perang, raja, para pastur hingga perdana menteri Romawi, Dubuqara menulis buku yang berjudul "Seratus Kiat Menghancurkan Khilafah Turki Usmani”.

Salah satu implementasi dari seratus strategi ini, umat Kristiani di eropa membentuk 13 organisasi menentang Turki. Salah satu organisasi ini bernama Organisasi Persatuan dan Pembangunan, yang mayoritas anggotanya adalah Yahudi. Masyarakat Turki mengakui keberadaan mereka dan menyebut mereka Dunamah yang berarti Atheis. Pemimpin kaum Dunamah ini adalah Mustafa Kamal, yang digelari pengikutnya sebagai Ataturk (Bapak Turki).

Pada tahun $1327 \mathrm{H} / 1909 \mathrm{M}$, organisasi Persatuan dan pembangunan dengan dukungan negara-negara Barat mendirikan gerakan oposisi yang menggerakkan mogok massal besar- besaran di Istambul. Dengan dalih ingin menghentikan mogok tersebut, pasukan organisasi bergerak dari markasnya di Salanika dan memasuki Istambul. Sesampainya di istambul, mereka menyingkirkan Khalifah Abdul Hamid II. Dan setelah itu, gereja berhasil mewujudkan ambisinya untuk meruntuhkan khilafah islamiyah.

\section{B. Fungsi Uang}

\section{Uang Sebagai Standar Ukuran Harga Dan Unit Hitungan}

Uang adalah standar ukuran harga, yaitu sebagai media pengukur nilai harga komoditas dan jasa, dan perbandingan harga komoditas dengan komoditas lainnya. Pada sistem barter, sangat sulit untuk mengetahui harga komoditas dengan harga komodias yang lainnya. Dan demikian pula dengan harga sebuah jasa terhadap jasa-jasa lainnya. ${ }^{11}$

Uang dalam fungsinya sebagai standar ukuran umum harga berlaku untuk ukuran nilai dan harga dalam ekonomi, seperti berlakunya standar meter untuk ukuran jarak, atau ampere untuk mengukur tegangan listrik, atau kilogram sebagai standar timbangan. Demikianlah uang sebagai alat yang mesti diperlukan untuk setiap perhitungan dalam ekonomi baik oleh produsen maupun konsumen. Tanpa hal itu, tidak mungkin baginya untuk melakukan perhitungan keuntungan atau biaya-biaya.

Ibnu al-Qayyim menegaskan dalam pernyataannya: "Dinar dan Dirham adalah harga komoditas. Dan harga adalah

\footnotetext{
${ }^{11}$ Hasan Ahmad, Loc. Cit.
} 
Rahmat Fauzi: Prospek Hukum Islam Di Bidang Penguatan Moneter Dengan Pemberlaku..

ukuran standar yang dengannya bisa dikenal ukuran nilai harta. Harus bersifat spesifik dan akurat, tidak naik dan tidak juga turun (nilainya)".

\section{Uang Sebagai Media Pertukaran}

Uang adalah alat tukar yang digunakan setiap individu untuk pertukaran barang dan jasa. Misalnya ada seseorang yang memiliki tomat dan ia membutuhkan beras, kalau dalam system barter orang yang memiliki tomat akan pergi ke pasar dan mencari orang yang memiliki beras dan membutuhkan tomat sehingga bisa terjadi pertukaran diantara keduanya.

Fungsi ini menjadi sangat penting dalam ekonomi maju, di mana pertukaran terjadi oleh banyak pihak. Setiap orang tidak memproduksi setiap apa yang ia butuhkan, tetapi terbatas pada barang tertentu, atau bagian dari barang atau jasa tertentu, yang dijual kepada orang-orang untuk selanjutnya ia gunakan untuk mendapatkan barang atau jasa yang ia butuhkan. Ketika seseorang memproduksi barang dan kemudian menjualnya dengan mendapatkan uang, selanjutnya ia gunakan untuk membeli kebutuhannya. Dengan demikian, uang membagi pertukaran kedalam dua macam:

\footnotetext{
a. Proses penjualan barang atau jasa dengan pembayaran uang;

b. Proses pembelian barang atau jasa dengan menggunakan uang.
}

\section{Uang sebagai Media Penyimpan Nilai}

Maksud para ahli ekonomi dalam ungkapan mereka, "uang sebagai media penyimpan nilai" adalah bahwa orang yang mendapatkan uang, terkadang tidak mengeluarkannya sekaligus, akan tetapi ia sisihkan sebagian untuk membeli kebutuhan pada waktu tertentu, atau ia menyimpan untuk hal-hal yang tidak terduga seperti sakit atau mendapatkan kerugian.

Al-Gazali menyinggung fungsi uang sebagai media penyimpan nilai yakni, "Kemudian dibutuhkan harta yang tahan lama karena keperluan yang terus menerus. Dan harta yang paling tahan lama adalah barang tambang maka dibuatlah uang dari emas, perak, dan tembaga".

Dalam pengertian ini ada dua penegasan, pertama: Islam mendorong investasi, tidak membekukan uang atau meminjamkannya (modal) dengan bunga, karena hal-hal itu menghalangi uang dari pembelanjaan investasi.

Kedua: bahwa nilai uang yang tidak tetap, dan daya tukar yang menurun menyebabkan kesulitan dalam fungsinya sebagai media penyimpan nilai untuk ditabung demi tujuan-tujuan dagang. Ini adalah yang dimaksudkan oleh ahli ekonomi sebagai dorongan mudharabah (spekulasi). 


\section{Konsep Uang dalam Ekonomi Konvensional}

Menurut teori ekonomi konvensional, uang dapat dilihat dari sisi hukum dan sisi fungsi. Secara hukum uang adalah sesuatu yang dirumuskan oleh undang- undang sebagai uang. Jadi segala sesuatu dapat diterima sebagai uang jika ada aturan atau hukum yang menunjukkan bahwa sesuatu itu dapat digunakan sebagai alat tukar. Sementara secara fungsi, yang dikatakan uang adalah segala sesuatu yang menjalankan fungsi sebagai uang, yaitu dapat dijadikan sebagai alat tukar menukar (medium of exchange) dan penyimpan nilai (store of value). Ini adalah pendapat Irving Fisher dan Cambridge. Sementara Keynes mengatakan, uang berfungsi sebagai alat untuk transaksi, spekulasi dan jaga-jaga. ${ }^{12}$

Di dalam ekonomi ini juga, uang dipandang sebagai sesuatu yang sangat berharga dan dapat berkembang dalam suatu waktu tertentu. Konsep ini disebut time value of money . adalah nilai waktu dari uang bisa bertambah dan berkurang sebagai akibat perjalanan waktu. Dengan memegang uang orang dapat dihadapkan pada resiko menurunnya daya beli dan kekayaan sebagai akibat inflasi. Sedangkan memilih menyimpan uang dalam bentuk surat berharga, pemilik akan memperoleh bunga yang diperkirakan di atas inflasi yang terjadi. Dengan demikian, nilai uang saat sekarang-nilai substitusinya terhadap

12 Jimly Asshiddiqie, 2010, Konstitusi ekonomi, Kompas, Jakarta, Hlm. 170 barang akan lebih tinggi dibandingkan nilai di masa yang akan datang. ${ }^{13}$

\section{Konsep Uang dalam Ekonomi Islam}

Sebagai perbandingan dengan teori ekonomi konvensional kapitalisme, islam membicarakan uang sebagai sarana penukar dan penyimpan nilai, tetapi uang bukanlah barang dagangan, mengapa uang berfungsi ? Uang menjadi berguna hanya jika ditukar dengan barang yang nyata atau digunakan untuk membeli jasa. Oleh karena itu, uang tidak bisa di jual dan dibeli secara kredit. Orang perlu memahami kebijakan Rasulullah SAW, bahwa tidak hanya mengumumkan bunga atas pinjaman sebagai sesuatu yang tidak sah tetapi juga melarang pertukaran uang dan beberapa benda bernilai lainnya untuk pertukaran yang tidak sama jumlahnya, serta menunda pembayaran jika barang dagangan atau mata uangnya adalah sama. Efeknya adalah mencegah bunga yang masuk ke system ekonomi melalui cara yang tidak di ketahui. Jika uang adalah flow concept maka modal adalah stock concept.

Di dalam ekonomi islam, konsep time value of money tentunya tidak akan terjadi. Untuk menganalisa ini, ada ajaran kuat dalam islam, yaitu terdapat di dalam QS. Al Ashr:1-3. Dari surah al Ashr ini menunjukkan bahwa waktu bagi semua orang adalah sama kuantitasnya, yaitu 24 jam/hari, 7 hari/minggu. Namun nilai dari waktu itu akan berbeda dari satu orang dengan orang lainnya. Perbedaan nilai

13 Shalah Ash-Shawi, 2008, Fikih Ekonomi Keuangan Islam, Darul Haq, Jakarta. Hlm. 13 
Rahmat Fauzi: Prospek Hukum Islam Di Bidang Penguatan Moneter Dengan Pemberlaku..

waktu tersebut adalah tergantung pada bagaimana seseorang memanfaatkan waktu. Semakin efektif dan efisien, maka akan semakin tinggi nilai waktunya. Efektif dan efisien akan mendatangkan keuntungan di dunia bagi siapa saja yang melaksakannya. Oleh karena itu, siapapun pelakunya tanpa memandang suku, agama dan ras, secara sunatullah ia akan mendapatkan keuntungan di dunia. Di dalam islam keuntungan bukan saja di dunia, namun yang dicari adalah keuntungan dunia dan akhirat. Oleh karena itu, pemanfaatan waktu bukan saja harus efisien dan efektif, namun juga harus didasari keimanan.

\section{E. Realitas Sistem Moneter Hari Ini, Khususnya dalam Penggunaan Uang}

Mungkin tidak sampai satu generasi ke depan, anak cucu kita akan menertawakan uang kertas yang kita pakai saat ini. Inilah yang terjadi dengan uang-uang kertas di dunia dari waktu ke waktu, maka ini pula yang kemungkinan besar akan terjadi dengan uang kertas yang ada pada zaman ini.

Ambil contoh dari beberapa ilustrasi di tulisan ini; ketika Islam sudah sangat maju dengan aturan main system keuangan berbasis Emas (Dinar) dan Perak (Dirham) yang ternyata valid sejak 14 abad lalu dan up-to-date sampai sekarang; dari generasi ke generasi manusia yang tidak mau belajar dari sejarah tidak bosan-bosannya bereksperimen dengan uang kertasnya. Berikut beberapa contoh diantaranya. ${ }^{14}$

Pada tahun 1777 ketika Amerika masih merupakan koloni Inggris dan berusaha mencetak uangnya sendiri. Saking tidak berharganya dan mudahnya di palsu, maka satu-satunya cara untuk menjaga nilainya dari pemalsuan hanya bisa dilakukan dengan menulis ancaman di uang tersebut bahwa pemalsu akan di hukum mati. ${ }^{15}$

Ketika Perang Dunia II usai ada salah satu Negara di Eropa Hungaria yang betul-betul kebingunan menentukan nilai uangnya, maka di cetaklah uang dengan nilai Seratus Juta Milyar Pengo (Pengo mata uang negeri itu). ${ }^{16}$

Uang kertas memang bersifat relatif dan identik dengan penguasa suatu negeri. Banyak hal yang tidak kalah lucunya yang terjadi dengan uang kertas zaman ini, hanya kita mungkin akan telat untuk tertawa. Berikut diantara fakta-faktanya: ${ }^{17}$

a. Uang Rupiah pernah secara revolusioner dibuang tiga angka nolnya tahun 1965/1966; tetapi kemudian tiga angka nol yang dibuang tersebut telah balik kembali ke uang kita hanya dalam tempo tiga

\footnotetext{
${ }^{14}$ Muhaimin Iqbal, Ironi uang Kerta. Diakse dari

http://www.geraidinar.com/index.php?option=com _content\&view=article\&id=231:ironi-uang-kertasdalam-sejarah\&catid=40:uang-fiat \&Itemid=91, pada tanggal 18 Oktober 2010 jan 9.48 WIB

15 Said Saad Marthon, Ekonomi Islam di tengah Krisis Ekonomi Global, Zikrul, Jakarta, Hlm. 71

${ }^{16}$ Muhamimin Iqbal, 2009, Dinar The Real Money, Gema Insani Press, Jakarta, Hlm. 52

17 Muhaimin Iqbal, 2008, Dinar Solution, Gema Insani Press, Jakarta. Hlm. 55
} 
puluh dua tahun kemudian. Bahkan tiga angka nol ini berganti menjadi empat atau bahkan lima. Buktinya, di dompet kita lebih banyak uang yang ber-angka nol 4 atau 5, karena yang nol 3 sudah pindah ke kenclengkencleng donasi.

b. Dengan bahan yang sama, dengan karya creative yang tidak kalah indah-nya uang kita hanya dinilai 1/10,000 dari uang negeri lain, negeri Paman Sam.

c. Uang kertas yang paling banyak dipakai di dunia saat ini adalah justru uang dari negeri yang paling banyak hutangnya.

d. Uang kertas dari salah satu negeri adhi kuasa telah menjadi candu bagi negara-negara lain yang menggunakannya; ketika negaranegara lain yang pintar dan sadar akan bahaya candu ini-pun mereka tidak mudah untuk menghentikan kecanduannya. Lihat tulisan saya tentang BRIC untuk ini.

Bayangkan kalau di Amerika tahun 1777 ada yang berpikir ke depan bahwa uang primitif mereka tidak akan survive; bayangkan kalau di Hungaria tahun 1946 ada yang mengingatkan kekonyolan pemerintahnya ketika mencetak uang kertas dengan nominal Seratus Juta Milyar Pengo yang daya belinya hanya 20 cent Dollar. Bayangkan pula kalau di negeri ini ada yang mengingatkan pemerintahan kita tahun 1965/1966 bahwa solusi sanering hanya efektif untuk sementara waktu.
Inilah yang coba kita sampaikan dan ingatkan, bukan karena kita tahu apa yang akan terjadi karena hanya Allahlah pemilik ilmu masa depan itu tetapi karena kehancuran uang kertas sudah terjadi berulang-ulang dalam sejarah, tidak ada yang menghalanginya untuk terulang kembali. $^{18}$

Sekitar tiga tahun lalu PBB pernah membuat konferensi pers yang mengejutkan dunia. Meskipun konferensi pers tersebut dinyatakan tidak resmi, namun sampai sekarang teksnya masih bisa di akses di situs resmi PBB.

Yang mengejutkan dunia waktu itu adalah angka-angka yang muncul di konferensi pers tersebut antara lain sebagai berikut $:^{19}$

a. Lebih dari $50 \%$ kemakmuran di dunia, dikuasai oleh hanya sekitar $2 \%$ penduduk dewasa dunia.

b. Sekitar $85 \%$ kemakmuran dunia berada di tangan sekitar $10 \%$ penduduk dewasa dunia.

c. $50 \%$ penduduk dewasa dunia hanya menguasai kurang lebih $1 \%$ kemakmuran dunia.

Para ahli kemudian mereka-reka, apa gerangan yang membuat dunia begitu timpangnya dalam hal kemakmuran ini? Masing-masing tentu punya jawaban sendiri sesuai dengan kompetensinya.

Ketimpangan ini tidak lain adalah karena penggunaan uang kertas yang tidak adil. Berikut adalah dua poin proses

\footnotetext{
${ }^{18}$ Ibid, Hlm. 56

${ }^{19}$ Ibid, Hlm. 57
} 
Rahmat Fauzi: Prospek Hukum Islam Di Bidang Penguatan Moneter Dengan Pemberlaku..

kemiskinan dunia yang ditimbulkan oleh sistem uang kertas ini:

a. Negeri yang ekonominya lemah, uang kertasnya cenderung terus melemah relatif terhadap uang kertas negeri yang kuat secara ekonomi. Asset-asset negeri yang lemah tersebut menjadi sangat murah karena nilainya diukur dengan uang kertas negeri tersebut. Asset-asset yang murah , sangat mudah dikuasai oleh negeri asing yang memiliki uang kertas yang lebih perkasa.

b. Di negeri yang ekonominya lemah, inflasi cenderung tinggi. Padahal inflasi ini adalah pajak tersembunyi yang tidak pandang bulu siapapun terkena tidak terkecuali penduduk paling miskin-pun di negeri itu.

Melalui dua mekanisme tersebut, negeri miskin akan semakin miskin, demikian pula penduduk miskin-nya akan terus berlipat ganda dan semakin miskin karena mereka juga terus dipajaki oleh apa yang disebut inflasi.

Sebagaimana penyebabnya yang jelas, pengobatannya sebenarnya juga sangat jelas. Berikut menurut saya pengobatan kemiskinan ini: ${ }^{20}$

a. Negara-negara dan seluruh institusi di dalamnya (termasuk institusi swasta), tidak lagi menghitung kekayaannya dengan alat ukur yang nilainya bias

\footnotetext{
${ }^{20}$ Muhaimin Iqbal, Uang yang Menimbulkan Ketimpangan Global, diakses dari http://www.geraidinar.com/index.php?option=com _content\&view=article\&id=224:uang-yangmenimbulkan-ketimpanganglobal $\&$ catid=40:uang-fiat $\&$ Itemid $=91, \quad$ pada tanggal 18 Oktober 2010 jam 10.00 WIB.
}

seperti uang kertas. Gunakan alat ukur yang baku sepanjang zaman seperti yang di ungkapan Imam Ghazali bahwa hanya emas dan perak lah yang dapat menjadi hakim yang adil dalam bermu'amalah-maka gunakanlah emas (Dinar) dan Perak (Dirham) sebagai alat ukur baku atau unit of account. Dengan demikian nilai kekayaan negeri-negeri tersebut terjaga dan tidak dapat dipermainkan melalui 'harga' uang kertas di pasar uang.

b. Negara harus bisa menekan inflasi sampai titik terendah sehingga tidak membebani penduduknya dengan inflasi sebagai 'pajak tersembunyi' bagi seluruh penduduk, termasuk yang paling miskin sekalipun. Dalam sejarah peradaban manusia hanya Dinar dan Dirham yang terbukti memiliki inflasi nol persen dalam tempo lebih dari 1400 tahun. Artinya hanya ada satu cara bagi negara untuk menekan inflasi yaitu dengan menggunakan uang yang memiliki nilai intrinsik; dan ini berarti yang paling praktis adalah Dinar dan Dirham.

Memang dengan hanya menggunakan Dinar dan Dirham tidak otomatis penduduk dunia menjadi makmur; begitu banyak yang harus diperbaiki terutama yang menyangkut keadilan ekonomi namun setidaknya penggunaan Dinar dan Dirham ini awalnya akan menyetop proses kemiskinan lebih lanjut. Dengan kerja keras berikutnya, maka 
kemakmuran akan merata bagi umat manusia di permukaan bumi.

Indahnya lagi penggunaan uang dengan nilai intrinsik ini dapat kita mulai kapan saja, tidak harus menunggu pemerintah atau negara memulainya. Kalau kita menggunakan kambing, sapi, emas, perak, beras, minyak, pohon, dsb sebagai 'uang' kita, maka tidak akan ada yang bisa melarang kita?

Memang fitrah di dunia ini segala sesuatu berpasang-pasangan; ada yang miskin ada pula yang kaya. Namun tidak berarti fitrah juga kalau yang kaya menjadi sangat sedikit sedangkan yang miskin sangat banyak seperti yang diungkapkan oleh PBB tersebut diatas; Bila ekonomi dunia dijalankan dengan sistem yang adil, maka hanya sedikit orang yang sangat kaya, sedikit pula orang yang sangat miskin dan yang paling banyak adalah kelompok menengah.

Jadi normalnya (fitrahnya) sistem ekonomi adalah bila sistem tersebut dapat menciptakan keadilan berupa antara lain akses modal, akses pasar dan yang juga sangat penting adalah akses nilai yang sama.

\section{SIMPULAN}

Sepanjang pemerintahan Islam, penggunaan dinar dan dirham merupakan hal yang sangat diprioritaskan karena ini akan sangat terkait dengan masalah kesejahteraan rakyat. Fungsi uang ada 3 yaitu Uang Sebagai Standar Ukuran Harga Dan Unit Hitungan, Uang Sebagai Media Pertukaran, dan Media penyimpan Nilai. Perbedaan konsep uang menurut
Islam dan Konvensional sangatlah berbeda jauh. Dalam Islam, faktor kemaslahatan ummat didahulukan, sedangkan ekonomi konvensional meletakkan uang sebagai hal untuk mencari keuntungan semata. Dalam realitas yang terjadi hari ini, masyarakat dunia sibuk menggunakan uang kertas yang sebenarnya tidak mempunyai arti apa-apa. Sedangkan Islam sudah mengajarkan sistem keuangan yang memang sifatnya menjamin konsistensi nilai uang yang ada.

Sebagai negara yang memiliki masyarakat Islam terbanyak, maka seharusnya kita kembali kepada sistem keuangan yang telah diajarkan Islam yaitu hukum Islam di bidang moneter.

\section{UCAPAN TERIMA KASIH}

Puji dan Syukur penulis ucapkan ke hadirat Allah SWT yang telah memberikan Rahmat dan Karunia-Nya, sehingga akhirnya penulis dapat menyelesaikan penulisan karya ilmiah ini yang berjudul: "Prospek Hukum Islam Di Bidang Penguatan Moneter Dengan Pemberlakuan Mata Uang Dinar Dan Dirham".

Penulis menyadari bahwa tanpa bantuan dan dorongan dari berbagai pihak tidak mungkin karya ilmiah ini dapat diselesaikan. Oleh karena itu pada kesempatan ini dengan segala kerendahan hati, penulis ingin mengucapkan terima kasih dan penghargaan yang sebesarbesarnya kepada:

1. Bapak Dr. Eviandi Ibrahim S.H., M.Hum selaku Ketua Sekolah Tinggi 
Rahmat Fauzi: Prospek Hukum Islam Di Bidang Penguatan Moneter Dengan Pemberlaku..

Ilmu Hukum Putri Maharaja Payakumbuh

2. Seluruh rekan-rekan Dosen Sekolah Tinggi Ilmu Hukum Putri Maharaja yang tidak dapat penulis sebutkan satu-persatu.

\section{DAFTAR PUSTAKA}

\section{Buku}

Bambang Sunggono, 2001, Metodologi Penelitian Hukum, Jakarta.

Karnaen A. Perwataatmadja, 2008, Jejak Rekam Ekonomi Islam Refleksi Peristiwa Ekonomi dan pemikiran Para Ahli Sepanjang Sejarah Kekhalifahan. Cicero Publishing. Jakarta.

Soerjono Soekanto, 1986, Pengantar Penelitian Hukum, Jakarta.
Jimly Asshiddiqie, 2010, Konstitusi ekonomi, , Kompas, Jakarta

Shalah Ash-Shawi, 2008, Fikih Ekonomi Keuangan Islam, Darul Haq, Jakarta

Said Saad Marthon, Ekonomi Islam di tengah Krisis Ekonomi Global, Zikrul, Jakarta

Muhamimin Iqbal, 2009, Dinar The Real Money, Gema Insani Press, Jakarta.

Muhaimin Iqbal, 2008, Dinar Solution, Gema Insani Press, Jakarta.

\section{Internet}

www.litbang.depkes.go.id

hendrakholid.net

www.geraidinar.com 